\title{
Influential Aspects of Women Engagement in Entrepreneurial Activities: A Study on Handicrafts Enterprise in Bangladesh
}

\author{
https://doi.org/10.21272/sec.3(2).89-99.2019
}

\author{
Md. Masihur Rahman \\ Professor, University of Rajshahi, Bangladesh
}

\section{Md. Abdullah}

Associate Professor, Cumilla University, Bangladesh

\begin{abstract}
Bangladesh has been showing tremendous advancement in empowering women in the society although Bangladesh is a male dominated society. Among the total number of entrepreneurs in Bangladesh, above 10\% are women. Many women have showed and proved their skills and beat their male counterparts in the small and cottage industries, especially the handicrafts sector; while many audacious entrepreneurs have excelled in Small and Medium Enterprises.

The study goals to scrutinize the influential aspects of women engagement in entrepreneurial activities of handicrafts enterprise in Bangladesh. The data is collected from 175 respondents by survey method through a structured questionnaire with five-point Likert scales \& multiple items. Convenience and judgmental sampling method are used. Data are analyzed using descriptive analysis (frequency, mean, and standard deviation), correlation analysis, and regression analysis. From the results of regression analysis, the study is showed that financial, business knowledge, and training program, which considerably influence on women engagement in handicrafts enterprise. The study creates consciousness among the women entrepreneurs, government and non-government areas, academicians, researchers, politicians and the investors. The results of the study may be applied by private and government firms, rural development academy, and investigators to encourage women engagement in entrepreneurial activities of handicrafts enterprise in Bangladesh. The study is limited merely women respondents who have already engaged in entrepreneurial activities of handicrafts enterprise for using questionnaire survey in Bangladesh. These investigators take exception to the fact the study is conducted in Dhaka city and women engaged in entrepreneurial activities of handicrafts enterprise is a small national portion. The examiners recommend that the study will be conducted in a more considerable area or in the whole of Bangladesh to determine the actual aspects that influence women engagement in entrepreneurial activities of handicrafts enterprise in Bangladesh.
\end{abstract}

Keywords: entrepreneurship, women engagement, SMEs, handicrafts, economic development.

JEL Classification: L26, L31, L32.

Cite as: Rahman, Md. M., Abdullah, Md. (2019). Influential Aspects of Women Engagement in Entrepreneurial Activities: A Study on Handicrafts Enterprise in Bangladesh. SocioEconomic Challenges, 3(2), 8999.https://doi.org/10.21272/sec.3(2).89-99.2019.

(C) The Authors, 2019. This article is published with open access at Sumy State University.

\section{Introduction}

Entrepreneurship all over the globe is introducing nowadays as a path for cost-effective employment, a means of aiding women to assert themselves in the globe of the job, and an avenue of improving both their financial and community position (Hassan \& Mugambi, 2013). Entrepreneurship is the dynamic procedure of creating, planning and building something original with value by dedicating the essential moment in time and attempt, assuming the accompanying psychical, output, innovation and employment, social risks, financial and receiving the resulting rewards of commercial and personal satisfaction and freedom (Hisrich, 2005Entrepreneurship is effectively recognized as a fundamental part of economic upliftment and a vital component in the try to lift countries from poverty (Wolfenson, 2001). The study is demonstrated that it is not deniable that women entrepreneurs are the principal actors in that division and contributors to the economic upliftment and are becoming increasingly visible in the local economies of the developing counties (Siwadi \& Mhangami, 2011). 
The study is focused predominately on women entrepreneurs in Small and Medium Enterprises (SMEs) sector based on data analysis and review of the critical recent literature. The study illustrated that in Asian developing countries SMEs are gaining overwhelming significance, more than $95 \%$ of all firms in all departments on average per state. The investigation also revealed that low level of education, lack of capital and cultural or religious constraints affect women entrepreneurs. However, the study depicted that better family incomes affect women entrepreneurs in SMEs (Tambunan, 2009). Fabayo (2009) presented that furthermore smallscale enterprises have been identified as a feeder service to large-scale companies. The European Commission (2003) defined enterprises as micro, small and medium-sized enterprises. Micro-enterprises are enterprises which have fewer than ten employees. Small enterprises have between ten to forty-nine employees, and they should have an annual turnover not exceeding \$7 million. Medium-sized enterprises have fewer than two hundred fifty employees and their annual turnover should not exceed $\$ 40$ million. The role of micro and small enterprises sector in the upliftment process has been at the Centre of the upliftment debate for the last three decades in Kenya and elsewhere in the world. Gradually more, the segment is perceived as a significant element in the creation of much-required employment, skills and generation of livelihoods for a rising number of people within the urban, semi-urban as well as the rural area (UNESCO, 2006). Women are eager to take big business and contribute to the Nations growth. Women entrepreneurship is identified and decided to promote stages in industry. Women entrepreneurship have to be appropriately manhandled with entrepreneurial traits and skills to meet the changes in trends, challenges global markets and also be compatible enough to keep up and strive for excellence in the SMEs sector (Vinesh, 2014). Women's enterprises are owned and controlled by women. The study depicted women take the quality and quantity of employment and how profits should be distributed or used vital decisions. In reality, also presented that ownership and control of SMEs can be complicated because of their close link with the patriarchal system which denies women power, even in activities they have initiated (McCormick \& Pedersen, 1998). Women create their self-enterprise and become entrepreneurs since opportunities of getting employment in either a private organization or government; non-government are currently decreasing (Gemechis, 2007). Women economic empowerment is an indispensable part of modern upliftment discourse in any upliftment undertaking of a nation. Women empowerment depends on taking portion in a variety of improvement functions. The study depicted women involvement in entrepreneurial activities has empowered them in social, economic and cultural fields. Despite recent improvement in the advancement and empowerment women in Bangladesh remain permeable to poverty and social deprivations (Jahed, et al., 2011). Surely, Bangladesh has been showing tremendous advancement in empowering women in the society although Bangladesh is a male dominated society. Among the total number of entrepreneurs in Bangladesh, above 10\% are women. Many women have showed and proved their skills and beat their male counterparts in the small and cottage industries, especially the handicrafts sector; while many courageous entrepreneurs have excelled in Small and Medium Enterprises. It's a good news for Bangladesh that in higher education, participation of women has been increased significantly. Ministry of education of the country shows that among the total students in university level $30.03 \%$ are women where in public university the rate is $34.26 \%$ and in private university the rate is $25.27 \%$.

The Broad objective of this study is to scrutinize the influential aspects of women engagement in entrepreneurial activities of handicrafts enterprise in Bangladesh. There are some Specific objectives of this research, which are given below: to show the level of intend to become entrepreneurs based on demographic characteristics; to examine the relationships between several aspects and women entrepreneurs development; to discover the influential facets of women participation in handicrafts enterprise.

This article is allocated into the following segments. Initially, the literature review and conceptual framework is provided based on the past study. Secondly, methodologies are explained which are applied to the study. Thirdly, the study is presented with the results and discussion. Lastly, the conclusion, limitations and further study.

\section{Literature Review and Conceptual Framework}

\subsection{Financial Aspects}

The financial facets of setting up a business are without scruple the most noteworthy obstacles to women (Zororo, 2011). Formal financial maintenance is observed to be too expensive for women entrepreneurs (Stevenson \& St-onge, 2005). Women entrepreneurs discovery it tough to upturn the start-up funds (Carter, et al., 2000). The paper is showed that financial freedom is pointedly inclined business choice (Schutte \& Barkhuizen, 2014). Financial sovereignty and availability of start-up funds aspects affected women decide to come to be entrepreneurs (Hossain, et al., 2009). Financial provision is inclined in women entrepreneur (Naser, 
et al., 2009). Accessing finance is key issues for women. Women entrepreneurs face the entree to tribute limitations for participation an enterprise. Women have fewer facilities than men to increase access to credit for several causes, comprising insufficiency of deposit, unwillingness to allow for household assets as collateral and undesirable perceptions of women entrepreneurs by loan providers (Mahbub, 2000). Inadequate access to finance is aspects that impact on women participation in entrepreneurial activities. The maximum constraint facing women entrepreneurs' access to finance is an issue due to collateral necessities (Athanne, 2011). Bangladesh has huge young women and creative employees that will get a chance to participate in Small and Medium Enterprises sector. The paper objectives to examine the aspects that influence women participation as entrepreneur in SMEs sector, economic development and its effect on poverty reduction. The exploration adopts the quantitative analysis of likely aspects that may influence women participation as entrepreneur in SMEs sector, economic development and its impact on poverty reduction. The study is revealed that financial as the important aspects, which are considerably influence women participation as entrepreneur in Small and Medium Enterprises (Hossain, A. et al., 2018). The study is exposed that adequate finance is considerably affected women participation towards entrepreneurial activities (Hasan, M. M. et al., 2018). Microcredit is an apparatus for socioeconomic progress. The United Nations (UN) stated 2005 the International Year of Microcredit (Delfiner, et al., 2006). Though, Grameen Bank lend both men and women at equivalent rates firstly, currently women became $95 \%$ of the bank's clients. $75 \%$ of the microcredit receivers are women in worldwide. Self-employment and women in entrepreneurship have been increasing in industrialized financial prudence for women to endure themselves and to aid support their relatives (Gordon, 2000). It is found out that women entrepreneurs do not have easy entry to micro finance aspects for entrepreneurial doings and as such have low trade performance because of low infrastructure amenities. The aim of this paper is to inspect the influence of credit, savings and training on women entrepreneurs' performance. The study decided that there is an effect of credit and training on income or profit other than existence and development (Rathiranee $\&$ Semasinghe, 2016). The most critical aspects contributing to women entrepreneur's success comprise good management skills, access to financing, personal abilities, and reasonable government support (Yusuf, 1995). Access to finance is a challenge common to all MSEs, the challenge for women business owners is compounded by the complicated gender associated difficulties that hinder their skill to access credit. To safe capital for initial business is one of the main difficulties of every entrepreneur predominantly in the MSE sector but women entrepreneurs face further limits to secure financial resources (Wole, 2009). Women access to finance is a main restraint to start and enlarge industries. Enlightening women direct access to credit clues to higher funds in human capital and have a stronger effect on a country economy in terms of health, education and long term inferences for relatives and humanities. There is a prodigious essential for women entrepreneurs to get access to credit amenities and the policy makers should comprehend and progress fruitful approaches to address the subject (World Bank, 2008). Hence, it is expected that:

H1: Financial aspects and women entrepreneurs are positively interrelated to each other.

\subsection{Business Knowledge Aspects}

Skill, knowledge and contacts are indispensable to enter new markets. Women usually deficiency access to knowledge in on how to participate in the entrepreneurial activities (UNECE, 2004). The results of the exploration designated strong relation between prior experiences and the decision to be entrepreneurs (Bequo \& Gehrels, 2014). Knowledge, expertise and experience are inclined in women entrepreneur. Women entrepreneurs have a low education level (Naser, et al., 2009). Lack of mindfulness, Illiteracy, administration talents and marketing skills are the aspects behind the success of the women entrepreneurs (Afroze, et al., 2014). Education and women entrepreneurship are interrelated (Mark, et al., 2006). Lack of linkages denies women consciousness and disclosure of entrepreneurship to good heroine replicas. Women have less knowledge of how to compact with the administrative bureaucracy, fewer enterprise contacts and fewer bargaining power, all of which additional limit entrepreneurship development (Mahbub, 2000). Compared to the size of the nation where an important increasement with population is visible and reasonably small size of the economy employment creation is a challenging task. Economic activities are influenced potential working women to participate in entrepreneurial activities. As a matter of fact, women entrepreneurship is a recent phenomenon in Bangladesh. Although women is taking to entrepreneurship in many challenging fields, their activities in Bangladesh are not that wide. In spite of fewer opportunities, many women have succeeded in business, but they are still very small in number. The basic purpose of the examination is to recognize the key aspects persuading women participation towards entrepreneurial activities and its impact on employment creation. The exploration is revealed that education, practical knowledge, and professional skills are significantly affected women participation towards entrepreneurial activities (Hasan, et al., 2018). The paper is verified that 
knowledge and skills are pointedly influenced women participation as entrepreneur in Small and Medium Enterprises sector particularly handicrafts enterprise and likewise the study is found that business experience, business plan, practical knowledge are influenced women entrepreneurs (Hossain, A. et al., 2018). Hence, it is expected that:

H2: Business knowledge aspects and women entrepreneurs are positively interrelated to each other.

\subsection{Socio-Cultural Aspects}

The paper is demonstrated that women immobility, poor support from society members and ethnicity influence negatively the performance of women SMEs. On the other hand, family roles, level of education and role models are significant aspects in cultivation the performance of women SMEs. The study normally accomplishes that SCFs have negative influence on the performance of women SMEs. This suggests that, women SMEs worried under such SCFs can't perform exceptionally. We mention that the government should express strategies that inspire women participation in entrepreneurial activities (Petro, et al., 2014). Values and beliefs shape performance may be engaged to influence the decision to become self-employed (Mueller \& Thomas, 2000). Gender differences in entrepreneurial activity are well documented in the literature (Brush, 2004). Gender issues relating to start-up and operating of businesses (Bequo \& Gehrels, 2014). Influence men and women in a different way to pursue entrepreneurship and become self-enterprises (Lituchy \& Reavly, 2004). Gender discrimination is remarkably affected women participation in entrepreneurial activities (Afroze, et al., 2014). Gemechis (2007), further social and cultural attitude towards youth entrepreneurship, entrepreneurship education and business assistance \& support, deterrents to accessing technology are important factors that affect entrepreneurial success. Women are affected by socio-cultural complexities to involve entrepreneurial activities (Nilufer, 2001). Deaux \& LaFrance (1998) indicated that personal aspiration is possible to be affected by personals from the same sex. Felicia et al. (2013) stated that socio-cultural morals and theories about entrepreneurship have a vital influence on motivational antecedents of entrepreneurial intention and business performance. This may perhaps have noteworthy effects on their self-confidence; achievement-motivation and even their enthusiasm to take risk, qualities that are faithfully connected to success in business (Rutashobya, 1995). Correspondingly, experimental proof shows that, the performance of women owned SMEs in Tanzania is different from that of their counterpart male (Tundui, 2012). This discloses that women as owner of SME are entrenched in a socio-cultural and individual aspect of culture a state which requisite investigates of knowledge. Hence, it is expected that:

H3: Socio-cultural aspects and women entrepreneurs are positively interrelated to each other.

\subsection{Family Support Aspects}

Entrepreneurship is the apparatus for social and economic development of any civilization. It energies people toward wealth and job creation which clues to better lives for people in the society. There has been increasing concern in entrepreneurship study in recent times. This paper endeavored to measure the effect of family in society. This is observed as crucial in a nation in which more than 125 ethnic communities are found. The results display that family has some influence in people to become entrepreneurship but it was not strongly authenticated by statistical tests. It is exposed that entrepreneur's maternal profession plays some role in entrepreneurship progress which is like to some results that maternal profession plays vital role in the choice of profession in children (Pant, 2015). The family support, husband's support in specific, influences women's entrepreneurs. Early socialization, experiences, role models and exposure also have influenced women to start their businesses (Marcellina, et al., 2002). Family commitment is influenced the entrepreneurial activities in less or more time (Holmquist \& Sundin, 1990). The most of the women make their own decision and few of them consult with other family members (JUDAI, 2002). Women's network is pronominally related to family links and may prove to be a barrier to business activities (Lin, 1999). The results of the study revealed that influence of family background on women's motivation and entrepreneurs' development (Bequo \& Gehrels, 2014). Single and widowed women have motivated participation in entrepreneurial activities to the married women in developing countries (Salehi-Isfahani, 2000). Family support may be affected on women entrepreneurs' personal difficulties during the venture start-up and management and also showed that in particular societies, family moral support can authorize the family members to interfere with the work, create conflict, and aggravate the women entrepreneurs difficulties. Correspondingly, women entrepreneurs lack of self-confidence and prevalent patriarchal mindsets can enable family members to influence and elevate personal difficulties (welsh, et al., 2014). The family delivers the entrepreneur with a diverse set of resources (Dyer \& Handler, 1994), which have the possible to influence the individual entrepreneur as well as the family 
business. The family business researchers have maintained that the family and the business are intertwined, represented as family effect (Dyer, 2006). As the family business is composed of multiple family members, the mechanical family ties will spill over to the business (Arregle, et al., 2007). Hence, it is expected that:

H4: Family support aspects and women entrepreneurs are positively interrelated to each other.

\subsection{Training Program Aspects}

Women have limited right of access to professional and automated training. In actual fact, women on regular have less entry to exercise than men and specialized and occupational talents can be developed on a strong substance of primary and secondary education (UNECE, 2004). Lack of satisfactory training for women is an obstacle to women participation in entrepreneurial activities. Particularly in the rural setting, the girl child is not given equal chance to train up like the boys; therefore they have restricted training which tended to affect entrepreneurs (Carter. et al., 2000). Non-availability of the training program and mechanical support are inclined women entrepreneurs (Afroze, et al., 2014). The study is found that qualified leaders \& trainers are affected women participation as entrepreneurs in Small and Medium Enterprise like handicrafts enterprise (Hossain, A. et al., 2018). The paper appraises the results of two entrepreneurship training programs functioning in the state of Vermont (1) the Women's Small Business Program which is run by Mercy Connections, a non-profit organization based in Burlington, and (2) the Micro Business Development Program, of the Vermont Community Action Agencies. Interviews with these entrepreneurs focused on their inspirations to start their own businesses, their meanings of success, the challenges and obstacles they faced, and the effects that training had (Bauer, K., 2011). The study is confirmed that skill training and education have positive effect on entrepreneurial performance (Akanji, 2006). Most of the women entrepreneurs have lack of opportunity in this regard mostly in emerging nations (Ibru, 2009). Business training programs are a common form of support to small businesses, but organizations providing this training often struggle to get business owners to attend. The training that is being presented is the ILO's GET ahead for women in enterprise programme. This programme highlights crucial entrepreneurial skills from a gender perspective, addressing the practical and strategies needs of low-income women in enterprise by strengthening their basic business and people management skills. The paper is revealed that women how to develop their personal entrepreneurial traits and obtain support through groups, network and institutions dealing with enterprise development (Bauer, S et al., 004). The effect of entrepreneurship training programmes on other factors of business performance such as income, sales, profits and inventory is modest. A meta-analysis of thirty seven programmes found that there is no impact on income (Cho \& Honorati, 2014). Entrepreneurship training programmes are premeditated to encourage selfemployment through business creation. Nevertheless, the effect of these programmes on start-up activity is modest. Evidence from such programmes found that self-employment declined in the long -term that is about two years after the intervention (De Mel et al., 2014). Hence, it is expected that:

H5: Training program aspects and women entrepreneurs are positively interrelated to each other.

2.6. Conceptual Framework

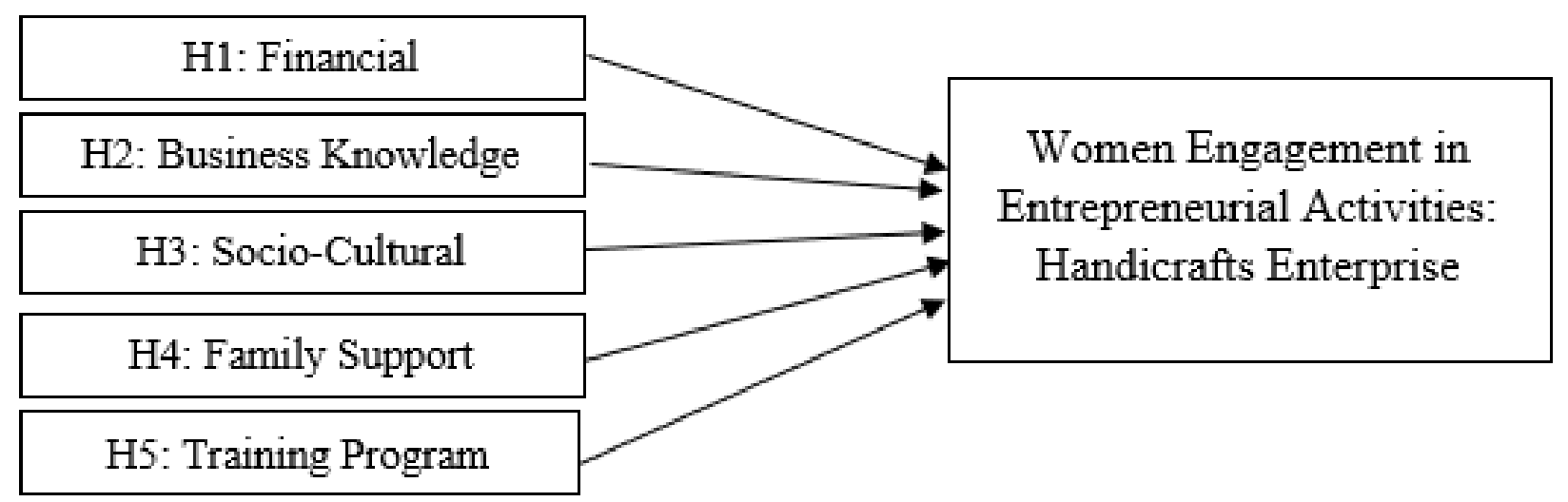

Figure 1. Proposed research model 


\section{Methodology of the study}

The investigation is quantitative. The type of information that is essential for this examination is mostly primary and all data have been collected from primary sources by the personal interview method. On the other hand, from the secondary sources, a literature review has been developed. A structural questions have prepared consists of 33 questions for data collections. The English version of the questionnaire was then translated from English to Bangla. Five questions are related to demographic variable like age, education qualification, monthly income, marital status. The numbers of 27 questions are about influential aspects of women participation in entrepreneurial activities of handicrafts enterprise. So, the section 2 is composed of women entrepreneurs measures by using five point Likert scales (from $1=$ 'Strongly disagree' to $5=$ 'Strongly agree'), there is first question with five propositions which are linked to the financial aspects (infrastructure, sufficient capital, available labor, raw materials, micro credit), the second question with six propositions which are linked to the business knowledge (education, innovative idea, practical knowledge, professional skills, experience, attend conference), the third question with five propositions which are linked to socio-cultural aspects (society attitude, positive association, social interaction, sex discrimination, ethnic stimulus), the fourth question with three propositions which are linked to family support aspects (spouse profession, father profession, responsibility for children \& husband), the fifth question with five propositions which are linked to training program (modern training method, skilled leaders $\&$ trainers, satisfactory application, education $\&$ training approach, right of entry to SMEs training) to influence women engagement in entrepreneurial activities of handicrafts enterprise. This questionnaire is developed from research on Factors Affecting Women Involvement as Entrepreneur in SMEs Sector, Economic Development and Its Impact on Poverty Reduction in Bangladesh (Hossain, A., et al., 2018). The study has been used Convenience sampling technique because it is readily convenient, available and generates relatively low cost. Primary data is collected through personal interview from 175 respondents. All constructs has no problems in reliabilities if the Cronbach's Alpha values exceeded the criterion of 0.700 . Cronbach's Alpha is 0.813 for 27 items of variable which suggest that the survey instrument is reliable to measure all constructs consistently and free from random error. Data collected from questionnaires are analyzed by using various statistical tools like descriptive analysis (frequency, mean, and standard deviation), correlation analysis, and regression analysis.

\section{Findings and Discussions}

Table 1. The Demographic Profile of Respondents

\begin{tabular}{|c|c|c|c|c|c|}
\hline Variable & Items & Frequency & Percentage & Valid percentage & $\begin{array}{l}\text { Cumulative } \\
\text { percentage }\end{array}$ \\
\hline \multirow{5}{*}{ Age } & 15-25 Years & 54 & 30.9 & 30.9 & 30.9 \\
\hline & 25-35 Years & 52 & 29.7 & 29.7 & 60.6 \\
\hline & 35-45 Years & 35 & 20.0 & 20.0 & 80.6 \\
\hline & 45 Years + & 34 & 19.4 & 19.4 & 100.0 \\
\hline & Total & 175 & 100.0 & 100.0 & \\
\hline \multirow{6}{*}{$\begin{array}{l}\text { Educational } \\
\text { Qualification }\end{array}$} & Below secondary & 4 & 2.3 & 2.3 & 2.3 \\
\hline & Secondary & 112 & 64.0 & 64.0 & 66.3 \\
\hline & Diploma & 16 & 9.1 & 9.1 & 75.4 \\
\hline & $\mathrm{BA}, \mathrm{BBA}$, and BCom & 41 & 23.4 & 23.4 & 98.9 \\
\hline & $\mathrm{MA}, \mathrm{MBA}$, and MSc & 2 & 1.1 & 1.1 & 100.0 \\
\hline & Total & 175 & 100.0 & 100.0 & \\
\hline \multirow{5}{*}{ Monthly Income } & Below 20000 & 65 & 37.1 & 37.1 & 37.1 \\
\hline & $20000-45000$ & 74 & 42.3 & 42.3 & 79.4 \\
\hline & $45000-70000$ & 32 & 18.3 & 18.3 & 97.7 \\
\hline & 700000 above & 4 & 2.3 & 2.3 & 100.0 \\
\hline & Total & 175 & 100.0 & 100.0 & \\
\hline \multirow{5}{*}{ Marital Status } & Single & 30 & 17.1 & 17.1 & 17.1 \\
\hline & Married & 115 & 65.7 & 65.7 & 82.9 \\
\hline & Divorced & 17 & 9.7 & 9.7 & 92.6 \\
\hline & Widow & 13 & 7.4 & 7.4 & 100.0 \\
\hline & Total & 175 & 100.0 & 100.0 & \\
\hline
\end{tabular}


Table 1 (cont.). The Demographic Profile of Respondents

\begin{tabular}{|l|l|c|c|c|c|}
\hline \multirow{2}{*}{ Variable } & \multicolumn{1}{|c|}{ Items } & Frequency & Percentage & Valid percentage & $\begin{array}{c}\text { Cumulative } \\
\text { percentage }\end{array}$ \\
\hline \multirow{4}{*}{$\begin{array}{l}\text { Business } \\
\text { Experience }\end{array}$} & Below 5 years & 115 & 65.7 & 65.7 & 65.7 \\
\cline { 2 - 6 } & 5-10 years & 53 & 30.3 & 30.3 & 96.0 \\
\cline { 2 - 6 } & 10-15 years & 5 & 2.9 & 2.9 & 98.9 \\
\cline { 2 - 6 } & 15 years Above & 2 & 1.1 & 1.1 & 100.0 \\
\cline { 2 - 6 } & Total & 175 & 100.0 & 100.0 & \\
\hline
\end{tabular}

Source: compiled by authors.

Table 1 presents the frequency and percentage on the demographic profile of respondents. It appears that respondents are mostly in the age categories 15-25 years old (30.9\%). The second highest of respondents are in the age categories $25-35$ years $(29.7 \%)$. The third highest of respondents are in the age categories 35-45 years (20.0\%), and Minority of respondents are in the age categories 45 years above (19\%). With regards to educational qualification, $64.0 \%$ of respondents are secondary level, $23.4 \%$ of respondents are BA, BBA, and BCom. 9.1\% of respondents are diploma, $2.3 \%$ of the respondents are below secondary, and only $1.1 \%$ respondents are MA, MBA, and MSc. These most of the respondents are secondary, and minority of the respondent is postgraduate. It presents that respondents are the majority in the income level 20,000-45,000 (42.3\%), the second highest of respondents are income level below 20,000 (37.1\%), the third highest of respondents are income level 45,000-70,000(18.3\%) and minority of respondents are income level 70,000 above (2.3\%). 65.7\% of those who have participation in the survey are married, $17.1 \%$ are single, $9.7 \%$ are divorced. Minority of respondents are widow (7.4\%). $65.7 \%$ of respondents have below 5 years' experience, $30.3 \%$ of respondents have $5-10$ years, $2.9 \%$ have $10-15$ years, and only $1.1 \%$ of respondents have 15 years above.

Table 2. Correlation analysis

\begin{tabular}{|l|c|c|c|c|c|c|}
\hline & 1 & 2 & 3 & 4 & 5 & 6 \\
\hline 1) Financial aspects & 1 & & & & & \\
\hline 2) Business knowledge aspects & $.464^{* *}$ & 1 & & & & \\
\hline 3) Socio-cultural aspects & $.636^{* *}$ & $.676^{* *}$ & 1 & & & \\
\hline 4) Family support aspects & $.567^{* *}$ & $.446^{* *}$ & $.477^{* *}$ & 1 & & \\
\hline 5) Training program aspects & $.621^{* *}$ & $.677^{* *}$ & $.678^{* *}$ & $.611^{* *}$ & 1 & \\
\hline 6) Women engagement & $.589^{* *}$ & $.537^{* *}$ & $.681^{* *}$ & $.601^{* *}$ & $.562^{* *}$ & 1 \\
\hline
\end{tabular}

Source: compiled by authors.

The inter-relationships between the six aspects (financial, business knowledge, socio-cultural, family support, training program, women engagement) are investigated using Pearson correlation analysis. The average score of the multi-items for a construct is calculated and the score is used in correlation analysis. Lind et al. (2010) specified that the correlations is strong when the value is $r=0.50$ to 1.0 or $r=-0.50$ to -1.0 . Results in Table 2 demonstrated that all variables are correlated together at the 0.01 level using the correlation test and the values ranges $r=0.589$ to $r=0.562$. Thus, there is no multicollinearity problem in the research.

Table 3. Descriptive Statistics analysis

\begin{tabular}{|l|c|c|}
\hline \multicolumn{1}{|c|}{ Aspects } & Average & Average \\
\hline \multicolumn{1}{|c|}{ Std. Deviation } \\
\hline 1) Financial aspects & Mean & .84317 \\
\hline 2) Business knowledge aspects & 4.00 & .94642 \\
\hline 3) Socio-cultural aspects & 4.09 & 1.000425 \\
\hline 4) Family support aspects & 3.98 & .732699 \\
\hline 5) Training program aspects & 4.34 & .781223 \\
\hline
\end{tabular}

Source: compiled by authors.

Table 3 discloses that majority of women have agreed financial aspects, business knowledge aspects, family suppoert aspects and training program aspects (mean score is 4 or more) become the notable facets in women engagement in handicrafts enterprise in Bangladesh. 
Table 4. Model Summary

\begin{tabular}{|c|c|c|c|c|}
\hline Model & R & R Square & Adjusted R Square & Std. Error of the Estimate \\
\hline 1 & $.577^{\mathrm{a}}$ & .333 & .313 & .43967 \\
\hline
\end{tabular}

Table 4 presents that correlation coefficient value $(R)$ is equal to 0.577 which recommends that there is moderate positive relationship between women entrepreneurs and financial, business knowledge, socio-cultural, family support, training program. However, only $33.3 \%$ (R-square values of 0.333 ) variation in women entrepreneurs are accounted due to independent variable. The adjusted $\mathrm{r}^{2}$ is 0.313 suggesting that the five aspects can significantly account for $31.3 .0 \%$ variance in the women entrepreneurs.

Source: compiled by authors.

Table 5. ANOVA ${ }^{\mathrm{a}}$

\begin{tabular}{|l|c|c|c|c|c|c|}
\hline \multicolumn{2}{|c|}{ Model } & Sum of Squares & df & Mean Square & F & Sig. \\
\hline \multirow{3}{*}{1} & Regression & 16.312 & 5 & 3.262 & 16.877 & $.000^{\text {b }}$ \\
\cline { 2 - 8 } & Residual & 32.670 & 169 & .193 & & \\
\cline { 2 - 8 } & Total & 48.982 & 174 & & & \\
\end{tabular}

Source: compiled by authors.

Table 5 reveals that multiple regression analysis is performed to scrutinize the relationship between influential aspects (financial, business knowledge, socio-cultural, family support, and training program) with women entrepreneurs. Five aspects are proposed and results are computed. The F- value is 16.877 with a significant level 0.000 which is less than 0.01 with 5 and 174 degrees of freedom and it assures model fitness for regression analysis.

Table 6. Coefficients ${ }^{\mathrm{a}}$

\begin{tabular}{|c|c|c|c|c|c|c|}
\hline & \multirow[t]{2}{*}{ Model } & \multicolumn{2}{|c|}{ Unstandardized Coefficients } & \multirow{2}{*}{$\begin{array}{c}\text { Standardized } \\
\text { Coefficients } \\
\text { Beta }\end{array}$} & \multirow[b]{2}{*}{$\mathrm{t}$} & \multirow[b]{2}{*}{ Sig. } \\
\hline & & B & Std. Error & & & \\
\hline \multirow{6}{*}{1} & (Constant) & 1.822 & .319 & & 5.719 & .000 \\
\hline & Financial aspects & .199 & .044 & .315 & 4.549 & .000 \\
\hline & Business knowledge aspects & .152 & .031 & .320 & 4.886 & .000 \\
\hline & Socio-cultural aspects & .011 & .031 & .024 & .357 & .721 \\
\hline & Family support aspects & .007 & .056 & .008 & .130 & .897 \\
\hline & Training program aspects & .157 & .057 & .181 & 2.767 & .006 \\
\hline
\end{tabular}

Note: a. Dependent Variable: Women engagement in entrepreneurial activities of Handicrafts enterprise.

Source: compiled by authors.

The results of multiple regression analysis in table 6 that financial as the important aspects, which significantly influence women entrepreneurs $(\beta 1=0.315 ; \mathrm{t}$-value $=4.549 ; \mathrm{p}<0.05)$. $\mathrm{H} 1$ is accepted. Therefore, financial aspects are influenced women participation in entrepreneurial activities of handicrafts enterprise. Then, business knowledge as the vital aspects, which notably impact on women entrepreneurs $(\beta 2=0.320$; $\mathrm{t}$-value $=$ 4.886; $\mathrm{p}<0.05)$. H2 is accepted. Consequently, business knowledge aspects are persuaded women participation in entrepreneurial activities of handicrafts enterprise. After, training program as the important aspects, which significantly influence women entrepreneurs $(\beta 5=0.181$; $\mathrm{t}$-value $=2.767 ; \mathrm{p}<0.05)$. H5 is accepted. Therefore, training program aspects are influenced women participation in entrepreneurial activities of handicrafts enterprise in Bangladesh.

The results in table 6 denotes that socio-cultural aspects insignificantly influence women entrepreneurs $(\beta 3=$ $0.024 ; \mathrm{t}$-value $=0.357 ; \mathrm{p}>0.05$ ). H3 is not accepted. Therefore, socio-cultural aspects have no effect on women participation in entrepreneurial activities of handicrafts enterprise. Next, family support aspects insignificantly impact on women entrepreneurs $(\beta 4=0.008$; $\mathrm{t}$-value $=0.130 ; \mathrm{p}>0.05)$. H4 is not accepted. Thus, family support aspects have no influence women participation in entrepreneurial activities of handicrafts enterprise in Bangladesh. 


\section{Conclusion, Limitation and Further Study}

The study has been undertaken with a purpose is to scrutinize the influential aspects of women engagement in entrepreneurial activities of handicrafts enterprise in Bangladesh. Numerous aspects are noteworthy apparatuses to encourage women engagement in entrepreneurial activities of handicrafts enterprise. The exploration scrutinizes financial, business knowledge, family support, socio-cultural, and training program aspects influence women engagement in entrepreneurial activities of handicrafts enterprise. From the results of regression analysis, the research is found that financial, business knowledge, and training program as the crucial aspects, which pointedly influence women engagement in entrepreneurial activities of handicrafts enterprise in Bangladesh. Up till now, the examination is reported that socio-cultural aspects insignificantly affect women engagement in entrepreneurial activities of handicrafts enterprise. This research is also presented that women face difficulties in engagement in entrepreneurial activities of handicrafts enterprise in Bangladesh. From regression analysis, family support and socio-cultural aren't affected women engagement in entrepreneurial activities of handicrafts enterprise. To amplify women engagement in entrepreneurial activities of handicrafts enterprise in Bangladesh. It would be strongly emphasized that the highlight of the study is on the fascinated women who are living in Bangladesh. The exploration generates consciousness among the women entrepreneurs, government and non-government areas, academicians, researchers, politicians and the investors. The outcomes of the study may be applied by private and government firms, rural development academy, and investigators to encourage women engagement in entrepreneurial activities of handicrafts enterprise in Bangladesh.

The study is limited merely women respondents who have already engaged in entrepreneurial activities of handicrafts enterprise for using questionnaire survey in Bangladesh. The Outcomes may vary over time and place. These results may not be applicable to other places. The examination found some effects of the independent variable. Thus, there may be some other variable which may affect women engagement in entrepreneurial activities of handicrafts enterprise. Those aspects are left for upcoming study. These investigators take exception to the fact the study is conducted in Dhaka city and women engaged in entrepreneurial activities of handicrafts enterprise is a small national portion. The examiners, therefore, recommends that the study will be conducted in a more considerable area or in the whole of Bangladesh to determine the actual aspects that influence women engagement in entrepreneurial activities of handicrafts enterprise in Bangladesh.

\section{References}

1. Afroze, T., Alam, M. K., Akther, E. \& Jui, N. S. (2014). Women entrepreneurs in Bangladesh- challenges and determining factors. Journal of Business and Technology (Dhaka), 9(02), 27-39.

2. Akanji, O. O. (2006). Microfinance as a strategy for poverty reduction. Central Bank of Nigeria Economic and Financial Review, 39(4).

3. Arregle, J. L., Hitt, M. S., Sirmon, D. G. \& Very, P. (2007). The development of organizational social capital: attributes of family firms. Journal of Management Studies, 44 (1), 73-95.

4. Athanne (2011). Entrepreneurship in Kenya. Nairobi.

5. Bauer, Finnegan, \& Haspels (2004). Gender and entrepreneurship Together: GET Ahead for Women in Enterprise: Training package and resource kit (Bangkok, Berlin and Geneva, ILO).

6. Bauer, K. (2011). Training Women for Success: An Evaluation of Entrepreneurship Training Programs In Vermont, USA. Journal of Entrepreneurship Education, 14, 1-24.

7. Bequo, I. \& Gehrels, S. A. (2014). Women entrepreneurship in developing countries. Research in Hospitality Management, 4(1\&2), 97-104.

8. Brush, C. G. (2004). Women-owned businesses: Obstacles and opportunities. Journal of Developmental Entrepreneurship, 2(1), 1-25.

9. Carter, S., Anderson, S. \& Shaw, E. (2000). Women's business ownership: A review of the academic, popular and internet literature, Report to the small business service. Available: http://business.king.ac.uk/research/kbssbs/womsbus.pdf

10. Cho \& Honorati (2014). Entrepreneurship programs in developing countries: A Meta regression analysis. Labour Economics, 28, 110-130.

11. Deaux, K. \& LaFrance, M. (1998). Gender in Gilbert, D., Fiske, S.T. and Lindzey, G. (Eds), Handbook of social psychology. 4th edn: Random House: New York, NY. 
SocioEconomic Challenges, Volume 3, Issue 2, 2019

ISSN (print) - 2520-6621, ISSN (online) - 2520-6214

12. Del Mel, McKenzie, \& Woodruff (2014). Business training and family enterprise start-up growth, and dynamics: experimental evidence from Sri Lanka, Journal of Development Economics, 106, 199-210.

13. Delfiner, M., Pailhe, C. \& Peron, S. (2006). Microinance: An analysis of experience and alternative regulations, Regulatory Research and Planning Department at the Central Bank of Argentina (BCRA).

14. Dyer, G. W. \& Handler, W. (1994). Entrepreneurship and family business: Exploring the connections. Entrepreneurship Theory and Practice, 19(1), 71-83.

15. Dyer, W. G. (2006). Examining the 'family effect' on firm performance. Family Business Review, 19 (4), 253-273.

16. European Commission (2003). Commission recommending concerning the definition of micro, small and medium sized enterprises Working paper 2003/361/EC, official Journal L124.

17. Fabayo, J. A. (2009). Small and medium enterprises development strategy: A critical option for sustainable long-term economic development in Nigeria. Paper presented at the first annual international conference on effective management of small and medium scale enterprises for sustainable economic development held at Abraham Adesanya Polytechnic. In Ijebu-Ode.

18. Felicia, O. J., George. O., Owoyemi, O. \& M. Adegboye (2013). Effects of Socio-Cultural Realities on the Nigerian Small and Medium Sized Enterprises (SMEs): Case of Small and Medium Sized Enterprises in Lagos State. International Journal of Business and Management, 9(1), 2014.

19. Gemechis, T. (2007). Attitude of college students towards entrepreneurship: A case study of Addis Ababa University and Rift Valley university college, (Addis Ababa, Ethiopia. Unpublished Thesis).

20. Gordon, D. (2000). Inequalities in income, wealth and standard of living in C. Pantazis and D. Gordon (eds) Tackling inequalities: Where are we now and what can be done? Bristol.

21. Hasan, M. M., Hossain, A. \& Khan, M. Y. H. (2018). Factors Persuading Female Participation towards Entrepreneurial Activities and Its Impact on Employment Creation. Socioeconomic Challenges, 2(3), 49-58.

22. Hassan, I. B. \& Mugambi, F. (2013). Determinants of growth for women owned and operated micro enterprises: The case of Garissa, Kenya. International Journal of Business and Commerce, 2(7), 45-55.

23. Hisrich, R. D. (2005). Entrepreneurship. Tata McGraw Hill: New Delhi.

24. Hossain, A., Siddique, M. Z. R. \& Jamil, M. A. A. (2018). Factors Affecting Women Involvement as Entrepreneur in SMEs Sector, Economic Development and Its Impact on Poverty Reduction in Bangladesh. Business, Management and Economics Research, 4 (5), 51-65.

25. Hossain, A., Naser, K., Zaman, A. \& Nuseibeh, N. (2009). Factors influencing women business development in the developing countries evidence from Bangladesh. International Journals of Organizational Analysis, 17(3), 202-24.

26. Ibru, C. (2009). Growing microfinance through new technologies. Federal University of Technology, Akure, Nigeria.

27. Jahed, A. M., Kulsum, U. \& Akther, S. (2011). Women entrepreneurship in Bangladesh: A study on support services available for its development and growth. Global Management Review, 5(3), 1-11.

28. JUDAI, (2002). The study on women entrepreneurs in Zambia. In Paper presented at National Conference on Women's Enterprise Development in Zambia. Lusaka.

29. Lin, N. (1999). Social network and status attainment. Annual Review of Sociology, 25, 476-87. Available: https://www.jstor.org/stable/223513.

30. Lituchy, T. \& Reavly, M. (2004). Women entrepreneurs: A comparison of international small business owners in poland and the czech republic. Journal of International Entrepreneurship, 2(1-2), 61-87.

31. Mahbub, U. H. (2000). Human development centre, human development in South Asia: The gender question (Oxford University Press), Disadvantages and self- enterprises. Women in Management Review, 19(1), 517.

32. Marcellina, C., Donath, R. O. \& Mariam, N. (2002). Jobs, gender and small enterprise in Tanzania: factors affecting women entrepreneurs in the MSE sector. ILO working paper.

33. Mark, W., Dickson, P. \& Wake, F. (2006). Entrepreneurship and education: What Is Known and not known about the links between education and entrepreneurial activity. The small business economy for data year 2005: A report to the president. USA Government printing office: Washington, DC. 84-113.

34. McCormick, D. \& Pedersen, P. O. (1998). Small enterprises: Flexibility and networking in an African context. Africa Today, 45(2), 259-72. 
35. Mueller, S. L. \& Thomas, A. S. (2000). Culture and entrepreneurial potential: A nine-country study of locus of control and innovativeness. Journal of Business Venturing, 16(1), 51-75.

36. Naser, K., Mohammed, R. W. \& Nuseibeh, R. (2009). Factors that affect women entrepreneurs: evidence from an emerging economy. International Journals of Organizational Analysis, 17(3), 225-47.

37. Nilufer, A. (2001). Jobs, gender and small enterprises in Bangladesh: factors affecting women enterprises in small and cottage industries in Bangladesh seed working paper, 14. International Labor office: Geneva.

38. Pant, S. K. (2015). Role of the Family in Entrepreneurship Development in Nepali Society, The Journal of Nepalese Business Studies, 9 (1), 37-47.

39. Petro, M., Annastazia, M. \& Robert, M. G. (2014). The Effects of Socio-Cultural Factors on the Performance of Women Small and Medium Enterprises in Tanzania. Journal of Economics and Sustainable Development, 5(21), 51-62.

40. Rathiranee \& Semasinghe (2016). The Impact of Micro Finance Factors on Women Entrepreneurs: Performance in Northern Sri Lanka. International Journal of Social Science Studies, 4(3), 94-99.

41. Rutashobya, L. (1995). Women Entrepreneurship in Tanzania: Entry and Performance Barriers. A research report submitted to OSSREA, Addis Ababa.

42. Salehi-Isfahani, D. (2000). Micro of growth in MENA-the role of households. Paper prepared for Global Research project. Cairo: Global Development Network.

43. Schutte, N. \& Barkhuizen, N., (2014). Factors affecting entrepreneurial and economic growth: The Namibian case. In Paper presented at Proceedings of 26th International Business Research Conference. Imperial College, London.

44. Siwadi, P. \& Mhangami, M. (2011). An analysis of the performance of women entrepreneurs in a Multicurrency economy: the case of Midlands's province of Zimbabwe. University of Botswana Journal.

45. Stevenson \& St-onge, A. (2005). Support for growth-Oriented women entrepreneurs in Kenya. International Labour Organization: Geneva.

46. Tambunan, T. (2009). Women entrepreneurship in Asian developing countries: Their development and main constraints. Journal of Development and Agricultural Economics, 1(2), 27-40.

47. Tundui, H. P. (2012). Gender and Small Business Growth in Tanzania: The Role of Habitus: University of Groningen, Groningen, the Netherlands, 161.

48. UNECE (2004). Women's Self Employment and Entrepreneurship in the ECE region background. Paper prepared by the secretariat for the Regional Symposium on Mainstreaming Gender into Economic Policies. Geneva.

49. UNESCO (2006). Gender inequalities in Kenya. UNESCO Publication

50. Vinesh (2014). Role of women entrepreneurs in India. Global Journal of Finance and Management, 6(5), 473-80.

51. Welsh, memili, kaciak \& Orchi (2014). Japanese women entrepreneurs: Implications for family firms. Journal of Small Business Management, 52(2), 286-305.

52. Wole, S. (2009). Challenges in Financing Women's Businesses. Ethiopia: Centre for African Women Economic Empowerment.

53. Wolfenson, J. D. (2001). Comparing the performance of male and Female-controlled businesses: relating output to inputs. Entrepreneurship Theory and Practice, 26(3), 91-100.

54. World Bank, (2008). World Development Report, Washington, DC.

55. Yusuf, A. (1995). Critical Success Factors for Small Business: Perceptions of South Pacific Entrepreneurs. Journal of Small Business Management, 33(2), 68-73.

56. Zororo, M. (2011). Characteristics and motivation in female entrepreneurship. Case of Botswana. University of Botswana Journal. 